\title{
Teologi Pendidikan: Konsep Pendidikan dalam Prespektif Islam
}

\author{
Dewi Fitriani ${ }^{1}$, Nurwadjah Ahmad EQ ${ }^{2}$, Andewi Suhartini ${ }^{3}$ \\ UIN Sunan Gunung Djati Bandung \\ dewiqueen@gmail.com,nurwadjah@uinsgd.ac.id
}

\begin{abstract}
Theology is an effort to contextualize religious teachings, not just textualizing, to answer human problems, not only problems of faith, monotheism but also cultural problems, problems of daily life, where the problems faced by humans are never-ending. In the context of Islam, the word theology will be more precise and meaningful when it is associated with the word Islam, so that the understanding of theology in question is theology that breathes Islam. An understanding of educational theology, in fact requires the inclusion of the conception of education and or deriving the concept of education in and from the schools of mutakallimin thought. Education is an interaction, namely the process of giving and taking, between humans and the environment. It is a process by which humans develop and create the skills needed to change and improve human conditions and their environment, as well as the formation of attitudes that guide their efforts to rebuild their human and physical characteristics. Education in Islam is often interpreted as At. Tarbiyahi (Education), the meaning is very thick and related to ar-riyadhah (practice). The training in question includes physical and spiritual training. The purpose of Islamic education is the formation of students to become servants of Allab who are pious and responsible for carrying out worldly and ukhrawi work.
\end{abstract}

Keywords: Theology, Islam, Education

\begin{abstract}
Abstrak : Teologi suatu usaha kontekstualisasi ajaran-ajaran agama bukan sekedar tekstualisasi, untuk menjawab persoalan-persoalan manusia, bukan hanya masalah keimanan, ketauhidan saja tetapi juga masalah budaya, masalah kehidupan seharai-hari, dimana persoalan yang dihadapi oleh manusia, tidak pernah habis-habisnya. Dalam kontek Agama Islam, kata teologi akan lebibih tepat dan bermakna apabila di kaitkan dengan kata Islam, sehingga pemahaman teologi yang dimaksud adalah teologi yang bernafaskan Islam. Pemahaman mengenai teologi pendidikan, pada kenyatannya menghendaki adanya memasukkan konsepsi pendidikan dan atau menurunkan konsepi pendidikan pada dan dari aliran-aliran mutakallimin. Pendidikan adalah suatu interaksi, yaitu proses memberi dan mengambil, antara manusia dengan lingkungan. Ia adalah proses dimana dan dengan itu manusia mengembangkan dan menciptakan ketrampilan-ketrampilan yang diperlukan untuk mengubah dan memperbaiki kondisi kemanusiaan dan lingkungannya, begitu juga pembentukan sikap yang membimbing usaha-usahanya membina kembali sifat-sifat kemanusian dan jasmaninya. Pendidikan dalam islam sering dimaknai dengan At.Tarbiyahi (Pendidikan), makna tersebut sangat kental dan terkait dengan ar-riyadhah (latihan). Adapun latihan yang dimaksud meliputi latihan jasmani dan rohani. Tujuan pendidikan Islam adalah terbentuknya anak didik menjadi hamba Allah yang taqwa dan bertanggung jawab melaksanakan pekerjaan duniawi dan ukhrowi
\end{abstract}

Kata Kunci: Teologi, Islam, Pendidikan

MANAZHIM : Jurnal Manajemen dan Ilmu Pendidikan

Volume 3, Nomor 2, Agustus 2021; 201-213

https:// ejournal.stitpn.ac.id/index.php/manazhim 


\section{PENDAHULUAN}

Teologi adalah sebuah paham atau pemikiran tentang peranan agama dalam mengatasi permasalahan sosial. Sebuah fakta empiris, bahwa agama yang semula datang untuk menjawab permasalahan-permasalah yang terjadi waktu turunnya agama, dan bisa menjawabnya dengan baik, namun seiring perjalanan waktu, kenyataanya menjadi semakin jauh dari peran solusi, bahkan hanya sekedar menjalankan peran ritual tradisional yang statis. Dengan kata lain, adalah suatu usaha kontekstualisasi ajaranajaran agama bukan sekedar tekstualisasi, untuk menjawab persoalan-persoalan manusia, bukan hanya masalah keimanan, ketauhidan saja tetapi juga masalah budaya, masalah kehidupan seharai-hari, dimana persoalan yang dihadapi oleh manusia, tidak pernah habis-habisnya. Budaya manusia berkembang terus dan siapapun tidak mingkin bisa menghentikan perkembangan budaya, sebagai konsekuensi Tuhan memberikan akal kepada manusia. Sementara Kitab suci, biarpun berlaku universal, tetap saja terbatas pada kaidah dan petunjuk secara garis besar. Mestinya kitab suci memang hanya mengatur prinsip-prinsip budaya saja dan aplikasi dan penerapannya biarlah itu urusan manusia. ${ }^{1}$

Dalam kontek Agama Islam, kata teologi akan lebibih tepat dan bermakna apabila di kaitkan dengan kata Islam, sehingga pemahaman teologi yang dimaksud adalah teologi yang bernafaskan Islam. Dengan demikian, maka ilmu kalam adalah ilmu yang dapat membuktikan kebenaran aqidah agama (Islam) dan menghilangkan kebimbangan dengan menggunakan hujah atau argumen. Menurut Tash Kubro Zadah teologi adalah cabang kelima dari ilmu-ilmu syari'at, yaitu usûl al-din yang disebut dengan ilmu kalam, yakni ilmu yang mampu membuktikan kebenaran akidah agama (Islam) dan menghilangkan keraguan dengan mengajukan argumentasi. ${ }^{2}$

Sedangkan Amin Abdullah memberikan pengertian teologi yang lebih fundamental, yaitu ilmu yang membahas tentang keyakinan dalam kehidupan beragama, yakni: suatu ilmu pengetahuan yang paling otoritatif, dimana semua hasil penelitian dan

${ }_{1}^{1}$ Zaghlul Yusuf, Ed, Pendidikan Agama Islam, analisis rangsangan Afeksi, MKDU-IKIP Jakarta, 1990, hal. 6-8.

2 Suroya Kiswati, Aljuwaeni Peletak Dasar Teologi Rasional Dalam Islam, (Gelora Aksara Pertama) 
pemikiran harus sesuai dengan alur pemikiran teologis, dan jika terjadi perselisihan, maka pandangan keagamaan yang harus dimenangkan. ${ }^{3}$

Kata teologi berasal dari bahasa Bahasa asing, yaitu; bahasa Inggris thelogy; berasal dari bahasa Yunani Theologia dari theos (Tuhan, Allah) dan logos (wacana ilmu). Dalam bahasa Yunani, teologi berasal dari dua kata, yaitu theos, yang berarti Tuhan, dan logia, yang berarti "kata-kata", "ucapan", atau wacana. ${ }^{4}$ Dengan demikian, secara etimologis teologi berarti suatu catatan atau wacana tentang para dewa atau Tuhan. Sedangkan secara terminologi William L. Resse, dalam Dictionary of Philosophy Religion, teologi berarti pengetahuan metodis, sistematis, dan koheren tentang seluruh kenyataan berdasarkan iman. ${ }^{5}$

Ajaran Islam mengharuskan Muslim mempunyai aqidah yang kuat dalam masalah ketuhanan, sebab hal itu termasuk masalah yang sangat pokok dalam sistem ajaran Islam yang tidak boleh diabaikan. Al-Quran yang menjadi sumbe keagamaan dan moral bagi Islam, mempunyai ajaran-ajaran dasar (basic teachings) yang bertujuan membentuk masyarakat yang terdiri atas individu-individu yang saleh, dengan kesadaran religius yang tinggi serta memiliki aqidah yang benar dan murni tentang Tuhan. Al-Quran juga memberikan bimbingan pada manusia bagaimana cara berhubungan, antara manusia dan Tuhan, manusia dan manusia, serta manusia dan alam. ${ }^{6}$

\footnotetext{
${ }^{3}$ Amin Abdullah, Studi Agama; Normativitas atau Historisitas, (Yogyakarta: Pustaka Pelajar, 1999), h. 10.

4 http://id.wikipedia.org/wiki/Teologi. diunduhpada, 7 juli 2021

5 4Teologi merupakan sebuah disiplin ilmu yang mele takkan kebenaran wahyu, lewat argumen filsafat dan ilmu pengetahuan yang independen. Lihat William L. Resse, dictionary of Philosophy Religion, (USA: Humanities Press Ltd, 1980), h. 28-29.

${ }^{6}$ Haerul Anwar, Teologi Islam Perspektif Fazlur Rahman, Ilmu Ushuluddin, Volume 2, Nomof 2 Juli 2014
} 


\section{PEMBAHASAN}

\section{Konsep Teologi Pendidikan}

Pemahaman mengenai teologi pendidikan, pada kenyatannya menghendaki adanya memasukkan konsepsi pendidikan dan atau menurunkan konsepi pendidikan pada dan dari aliran-aliran mutakallimin. Konsepi pendidikan yang diturunkan cenderung disesuaikan dengan pemahaman Mu'tazilah, qadariyyah, jabbariyyah, dan yang lainnya, misalnya. Pemahaman seperti ini akan mengabaikan sebuah frame besar teologi, atau hanya mengarah pada tema-tema kalam yang saling diperdebatkan lalu diderivasikan menjadi sebuah konsepsi pendidikan. ${ }^{7}$

Teologi pendidikan merupakan kajian konsepsi pendidikan yang di-derivasikan dari penalaran kritis mengenai Tuhan (teos) yang meliputi eksistensi dan "atribut" ketuhanannya. Dan penalaran kritis mengenai Tuhan ini tidak dapat dipisahkan dari memahami pesan-pesan Tuhan, termasuk di dalamnya pernyataan-pernyataan wahyu Tuhan. Konten pembahasan pada teologi pendidikan tidak dapat dipisahkan dari kajian mengenai pesan wahyu atau ayat juga interpretasinya.

Alhasil konten mengenai teologi pendidikan tersebut merupakan wacana baru yang konstruktif dan paradigmatic bagi upaya mengembangkan khazanah pengetahuan dan pendidikan Islam itu sendiri yang didasarkan pada sudut pandang Ketuhanan (aspek Teologis), Kesatuan Alam (Aspek Kosmologis), Kesatuan Kemanusiaaan (Aspek Antro-Sosiologis). ${ }^{8}$

\section{Pendidikan dalam Islam}

Dalam Incyclopedia of Education (Monroe), pendidikan diartikan sebagai suatu kegiatan yang berkaitan dengan sejumlah proses dari suatu kelompok sosial. Sementara Peters (1980) menyatakan bahwa pendidikan itu tidak lebih dari suatu aktivitas pembaharuan dalam kepribadian yang lebih baik. Petterson (1979) memberikan definisi, bahwa Pendidikan ialah usaha untuk mengubah dan memindahkan nilai-nilai budaya kepada setiap individu dalam masyarakat. Namun ada

\footnotetext{
${ }^{7}$ Malik Fatoni, teologi pendidikan; Studi analisa penguatan dalam Karakteristik pendidikan islam, Jurnal Geneologi PAI Volume 1 No 1 (Januari-Juni) 2016

8 Muhammad Irfan \& Mastuki. Teologi Pendidikan; Tauhid Sebagai Paradigma Pendidikan Islam. Jakarta, Friska Agung Insani. Cet. III. 2008. Hal..4 
yang berpendapat bahwa pendidikan adalah usaha membantu mansia menjadi manusia. ${ }^{9}$ Memberikan pertolongan, menanamkan dan membentuk suatu karakter atau kebiasaan dan tabiat baik tidak lepas dari sebuah proses panjang yang namanya Pendidikan. Pendidikan dalam Islam adalah suatu kegiatan yang merupakan bagian dari kegiatan dakwah. Jika Al-Attas (1980) menyatakan bahwa istilah tarbiyah yang diartikan pendidikan, tidak terdapat dalam kamus besar Bahasa Arab, namun dalam kata yang dibentuk dari kata dasar Rabb, ada didalam Al-Qur'an, seperti disebutkan antara lain dalam sebuah do'a:

$$
\text { رَبِّ ارْحَمْهُهَا كَمَا رَبَيَّانِي صَغِيرًا }
$$

"Wahai Tubanku, kasibilah mereka keduanya, sebagaimana mereka berdua telah mendidik aku waktu kecil"no

Atau

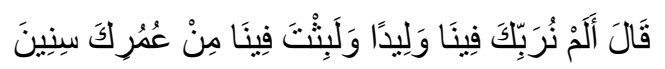

"Fir'aun menjawab: "Bukankah kami telah mengasubmu di antara (keluarga) kami, waktu kamu masib kanak-kanak dan kamu tinggal bersama kami beberapa tabun dari umurmu."'1

Pendidikan adalah suatu interaksi, yaitu proses memberi dan mengambil, antara manusia dengan lingkungan. Ia adalah proses dimana dan dengan itu manusia mengembangkan dan menciptakan ketrampilan-ketrampilan yang diperlukan untuk mengubah dan memperbaiki kondisi kemanusiaan dan lingkungannya, begitu juga pembentukan sikap yang membimbing usaha-usahanya membina kembali sifat-sifat kemanusian dan jasmaninya. ${ }^{12}$

Ahmad tafsir (2006) menyatakan bahwa Pendidikan adalah sebuah proses menolong manusia agar menjadi manusia. Manusia sebagai subyek pendidikan, ada yang berhasil manjadi manusia tetapi banyak yang tidak berhasil, yang oleh Al-Qur'an disebut sebagai lebih rendah derajadnya dibanding Hewan "sungguh aku telah ciptakan

${ }^{9}$ Mehdi Nakosteen, dalam buku, History of Islamic Origins of Western Education A.D. 800-1350; with an introduction to Medieval Muslim Education, University of Colorado Press, Boulder,1964.

10 Al-Qur'an, Surat Isra' ayat 24

11 Al-Qur'an, Surat Assyura ayat 18

12 Hasan Langgulun, Pendidikan Islam Dalam Abad 21,PT Pustaka Al-Husna Baru, Jakarta 2003 hal 70 
manusia dalam sebaik-baiknya penciptaan, tapi kemudian bisa jadi mereka akan berada ditempat yang serendah-rendahnya"13 makanya ada manusia yang baik, dan ada manusia yang tidak baik.

Mendidik yang baik adalah menanamkan nilai-nilai kebaikan kepada subyek didik, sehingga kilak menjadi manusia yang baik. Kebaikan manusia bisa saja diukur dengan ukuran yang berbeda, bisa dengan ukuran agama, bisa dengan ukuran etis dan bisa pula dengan ukuran rasio. Bukankah jika seseorang itu menjadi baik berarti mengangkat harkat dan martabatnya sandiri, dan sebaliknya jika gagal berarti merendahkan derajat dan martabatnya sendiri pula. Oleh karenanya, yang namanya proses pendidikan itu tidak pernah mengenal kata sudah selesai, tetapi selalu dalam kondisi belum selesai dan masih terus berproses hingga akhir hayat (long live education) yang dalam hadis Nabi disebutkan dari buaian sampai liang lahat.

Orang yang belum menjadi baik akan tetap ada kesempatan untuk menjadi baik, sedangkan orang yang sudah baik, harus mempertahankan dan terus meningkatkan kualitas kebaikannya. Kualitas kebaikan dapat berasalal dari pola berfikirnya yang intelek, dari ketelitian, keterampilannya dan akhlaknya yang mulya dalam mengaplikasikan agamanya dan dari ketakwaannya. ${ }^{14}$

Pendidikan dalam Islam adalah pendidikan yang di dasarkan pada ajaran islam, Islam sebagai sebuah ajaran agama yang diajarkan dan di bawa oleh Muhammad SAW, yang berisikan seperangkat ajaran tentang kehidupan manusia, ajaran yang dirumuskan berdasarkan sumber pada al-quran dan hadits serta berdasarkan pemaparan rasio akal. ${ }^{15}$

Pendidikan Islam sebagai sebuah paradigma tidak bisa dilepaskan dari fondasifondasi yang menopang lahirnya paradigma tersebut. Hasan Langgulung, memandang bahwa fondasi pendidikan itu adalah pesan Ilahiah (al-quran dan sunnah) dan landasan pemikiran yang mengitarinya. ${ }^{16}$ Landasan-landasan ini tidak bisa dipisahkan dari konsepsi teologis pendidikan yang berhubungan dengan Tuhan dan manusia. ${ }^{17}$ Hasan

13 Al-Qur'an, Surah At-Tin ayat 4-5

${ }^{14}$ Lebih rinci, baca Zaghlul Yusuf, Sistem Pendidikaqn Islam, FKIP-UIA, 1992, hal. 54 dan seterusnya

15 Ahmad Tafsir. Ilmu Pendidikan dalam Perspektif Islam. Bandung. Rosda Karya. 2010. Hal. 18

${ }^{16}$ Hasan Langgulung. Asas-Asas Pendidikan Islam. Jakarta. Al-Husna. 1987. Hal. 14

17 Saefullah. Muhammad Qutub dan Sistem Pendidikan Non-Dikotomik. Yogyakarta. Suluh Pers. 2005. 
Langgulung mendefinisikan pendidikan Islam adalah proses penyiapan generasi muda untuk mengisi peranan, memindahkan pengetahuan dan nilai-nilai Islam yang diselaraskan dengan fungsi manusia untuk beramal di dunia dan memetik hasilnya di akhirat. $^{18}$

Konsepsi Tuhan dalam Islam memiliki peranan penting dalam merumuskan sebuah konsepsi pendidikan Islam. Pemahaman Tuhan dalam Islam yang disenyalir dalam pesan Tuhan juga atribut yang mengitarinya merupakan sebuah dasar bagi pengembangan konsepsi pendidikan Islam. Nuansa pemikiran teologis semacam ini menghendaki adanya sebuah pola pikir integral-reflektif, tidak sebatas memahami simbol-simbol ketuhanan dalam pesan-Nya. Lebih dari itu, pemahaman dialektis dan filosofis sangat menguatkan argumentasi konsepsi ketuhanan yang diderivasikan pada konsepsi pendidikan Islam. Paradigma pendidikan berbasis teologis ini tidak sematamata dipancari oleh pemahaman mengenai teologi ketuhanan. Untuk membangun sebuah paradigma pendidikan yang teologis, konsepsi mengenai manusia turut mewarnai konstruksi paradigma pendidikan. ${ }^{19}$

Pendapat Abudin Nata setidaknya mempertegas posisi dan kedudukan komprehensif diatas bahwa setidaknya ada empat ruang lingkup yang harus dipenuhi untuk dapat membentuk sistem pendidikan dalam Islam yang baik. Ruang lingkup itu antara lain: ${ }^{20}$

1) Ilmu pendidikan Islam haruslah bersifat normative ferenialis, yaitu ilmu pendidikan Islam harus di bangun atas dasar pemahaman terhadap ajaran yang terdapat dalam al-qur'an dan assunah dengan menggunakan cara-cara tertentu.

2) Ilmu pendidikan Islam haruslah bersifat filosofis, karena ilmu pendidikan islam harus di bangun atas dasar pemikiran filsafat islam.

3) Ilmu pendidikan Islam haruslah bersifat historis-empiris, artinya ilmu pendidikan islam haruslah di bangun atas dasar data-data yang dapat

${ }^{18}$ Hasan Langgulung, Beberapa Pemikiran tentang Pendidikan Islam, Bandung: al-Ma arif, 2001, hlm. 94.

${ }^{19}$ Malik Fatoni, teologi pendidikan; Studi analisa penguatan dalam Karakteristik pendidikan islam, Jurnal Geneologi PAI Volume 1 No 1 (Januari-Juni) 2016

20 Abudin Nata. Filsafat Pendidikan Islam. Jakarta. Gaya Media Pratama. 2005. Hal.4 
dijumpai dalam sejarah dan bahkan masih bisa disaksikan dan di baca melalui laporan ilmiah.

4) Ilmu pendidikan islam haruslah bersifat aplikatif, artinya ilmu pendidkan islam haruslah berisikan informasi mengenai penerapan dari konsep dan teori dalam kegiatan pendidikan dan pengajaran.

Pendidikan dalam islam sering dimaknai dengan At.Tarbiyahi (Pendidikan), makna tersebut sangat kental dan terkait dengan ar-riyadhah (latihan). Adapun latihan yang dimaksud meliputi latihan jasmani dan rohani sebagaimana dalam firman Allah dikatakan Qs. Al- Qashash ayat 77:

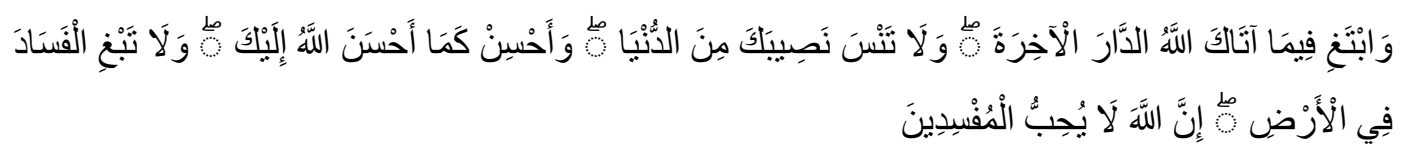

Dan carilah pada apa yang telah dianugerabkan Allah kepadamu (kebahagiaan) negeri akhirat, dan janganlah kamu melupakan bahagianmu dari (kenikmatan) duniawi dan berbuat baiklah (kepada orang lain) sebagaimana Allah telah berbuat baik, kepadamu, dan janganlah kamu berbuat kerusakan di (muka) bumi. Sesunggubnya Allah tidak menyukai orang-orang yang berbuat kerusakan.

Konsep duniawi disana adalah keharusan kita meraih cita-cita bagi kehidupannya dengan cara melatih diri dan berusaha sungguh-sungguh dalam mempelajari kekuasaannya. Semua itu dapatlah dilaraih hanya dengan pendidikan, tentunya pendidikan Islam yang dimaksudkan. ${ }^{21}$

\section{Dasar Pendidikan Islam}

Sekurang-kurangnya ada lima unsur yang dibahas dalam ilmu pendidikan Islam, yaitu: "Dasar dan Tujuan Pendidikan Islam, Pendidikan dalam Pendidikan Islam, Peserta didik dalam Pendidikan Islam, Materi atau kurikulum Pendidikan Islam, dan Metode dalam Pendidikan Islam." 22 Dasar adalah landasan untuk berdirinya sesuatu.

21 Assyabani At-Thouimi \& Umar Muhammad Filsafat Pendidikan Islam, Terj. Hasan Langgulung. Jakarta Bulan Bintang. 1979. Hal. 132-133

${ }_{22}$ Mangun Budiyanto, Ilmu Pendidikan Islam, (Yogyakarta: Penerbit Ombak, 2013) h.10-12

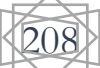


Fungsi dasar ialah memberikan arah kepada tujuan yang akan dicapai dan sekaligus sebagai landasan untuk berdirinya sesuatu. ${ }^{23}$

Dasar ideal pendidikan agama Islam ialah memberikan arah kepada tujuan yang akan dicapai dan sekaligus sebagai landasan untuk berdirinya sesuatu. Dasar pendidikan Islam adalah identik ajaran Islam itu sendiri. Keduanya berasal dari sumber yang sama yaitu Al-Qur'an dan Hadits. 'Kemudian dasar tadi dapat dikembangkan dalam pemahaman para ulama dalam bentuk Al-Qur'an, sunah (hadits), perkataan, perbuatan, dan sikap para sahabat, dan ijtihad." ${ }^{24}$ Dasar pendidikan Islam dapat dibagi kepada tiga kategori yaitu: dasar pokok, dasar tambahan dan dasar operasional. ${ }^{25}$ :

a. Dasar Pokok

1) Al-Qur'an

Sangat banyak ayat Al-Qur'an yang menunjukkan betapa besar perhatian Islam terhadap pendidikan dan pengajaran pada khususnya, serta ilmu pengetahuan pada umumnya. Antara lain bisa dibaca pada QS. At-Tahrim ayat 6 Firman Allah SWT sebagai berikut:

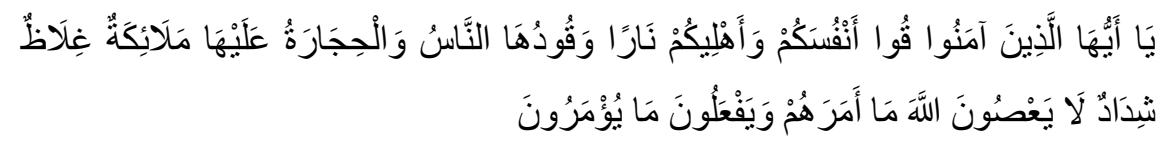

"Hai orang-orang yang beriman, peliharalah dirimu dan keluargamu dari api neraka yang bahan bakarnya adalah manusia dan batu; penjaganya malaikatmalaikat yang kasar, keras, dan tidak mendurbakai Allah terbadap apa yang diperintabkan-Nya kepada mereka dan selalu mengerjakan apa yang diperintabkan."

2) Sunnah

Ajaran yang kedua selain Al-Qur'an adalah Sunnah Rasulullah SAW.yaitu amalan yang dikerjakan oleh Rasulullah SAW. dalam proses perubahan hidup sehari-hari menjadi sumber utama pendidikan Islam

\footnotetext{
${ }^{23}$ Ramayulis, Ilmu Pendidikan Islam, Jakarta: Kalam Mulia, 2011.h.121

24 Aat Syafaat, Sohari Sahrani, Peranan Pendidikan Agama Islam Dalam Mencegah Kenakalan Remaja 2017

${ }^{25}$ Ramayulis, Ilmu Pendidikan Islam, Jakarta: Kalam Mulia, 2011. h. 122.
} 
karena Allah SWT"' sehingga menjadikan Muhammad SAW sebagai teladan bagi umatnya. ${ }^{26}$

Nabi SAW. bersabda: "Seorang laki-laki itu adalah pemimpin di dalam keluarganya dan ia akan dimintai pertanggungjawaban atas kepemimpinannya itu. Wanita juga pemimpin di rumah suaminya dan ia akan dimintai pertanggungjawaban atas kepemimpinannya itu" ( HR. Bukhari Muslim).

b. Dasar Tambahan

1) Perkataan, Perbuatan, dan Sikap Para Sahabat

Mereka telah mendapat pengajaran langsung dari pendidik terbaik yang ada diatas bumi ini, yaitu Rasulullah SAW. "Melalui perantaran merekalah, generasi setelahnya hingga generasi kita sekarang ini dapat mengetahui dan mempelajari serta mengerti Al-Qur'an dan Sunnah"27 Pada masa al-Khulafa al-Rasyidin sumber pendidikan dalam Islam sudah mengalami perkembangan.Selain Al-Qur'an dan Sunnah juga perkataan, sikap dan perbuatan para sahabat.Perkataan mereka dapat dijadikan pegangan karena Allah SW'T.sendiri di dalam Al-Qur'an yang memberikan pernyataan. ${ }^{28}$

Firman Allah SWT dalam QS. At-Taubah: 119:

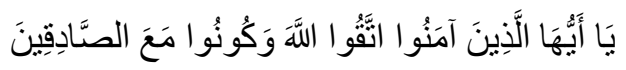

"Hai orang-orangyang beriman bertakwalah kepada Allah, dan hendaklah kamu bersama orang-orang yang benar.”

2) Ijtihad

Ijtihad berasal dari kata "jahda", artinya "al-ma'yaqqab” yang artinya sulit atau berat, susah atau sukar. Kata jahda yaitu pengerahan segala kesanggupan dan kekuatan atau berarti juga berlebih-lebihan dalam

26 Aat Syafaat, Sohari Sahrani, Peranan Pendidikan Agama Islam Dalam Mencegah Kenakalan Remaja., h. 22 .

27 Mangun Budiyanto, Ilmu Pendidikan Islam, Yogyakarta: Penerbit Ombak, 2013. h.25.

${ }^{28}$ Ramayulis, Ilmu Pendidikan Islam, Jakarta: Kalam Mulia, 2011, h.124. 
sumpah. Sedangkan menurut istilah ijtihad adalah menggunakan seluruh kesanggupan untuk menetapkan hukum-hukum syariah. ${ }^{29}$

c. Dasar Oprasional

Dasar pendidikan Islam merupakan landasan operasional untuk merealisasikan dasar ideal atau sumber pendidikan Islam. Menurut Hasan Langgulung, dasar operasional pendidikan Islam ada enam yaitu: historis, sosiologis, ekonomi, politik, dan administrasi, psikologis, dan filosofis. ${ }^{30}$

\section{Tujuan Pendidikan Islam}

Tujuan pendidikan merupakan masalah sentral dalam pendidikan. Sebab, tanpa perumusan yang jelas tentang tujuan pendidikan, perbuatan menjadi acak-acakan, tanpa arah, bahkan bisa sesat atau salah langkah. ${ }^{31}$ Tujuan pendidikan agama Islam ialah memberikan bantuan kepada manusia yang belum dewasa, supaya cakap menyelesaikan tugas hidupnya yang diridhai Allah SWT. sehingga terjalinlah kebahagian dunia dan akhirat atas kuasanya sendiri. Tujuan pendidikan Islam yang terakhir ialah terbentuknya kepribadian muslim. Yang maksudnya kepribadian muslim ialah kepribadian yang seluruh aspek-aspeknya yakni baik tingkah laku luarnya kegiatan-kegiatan jiwanya, maupun filsafat hidup dan kepercayaannya menunjukkan pengabdian kepada Tuhan, penyerahan diri kepada-Nya. ${ }^{32}$

Tujuan Allah SWT. menciptakan manusia dapat kita ketahui pada firman Allah SWT dalam QS. Adz-Dzariyat: 56:

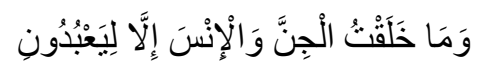

"Dan aku tidak menciptakan jin dan manusia melainkan supaya mereka mengabdi kepada-Ku."

Pada lain ayat Allah SWT. ditegaskan menyatakan dengan firman-Nya QS.AlBayinah: 5 :

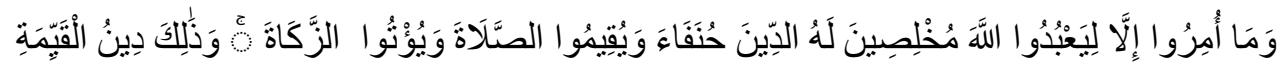

\footnotetext{
${ }^{29}$ Beni Ahmad Saebani dan Abdul Hamid, Ilmu Akhlak, (Bandung: Cv Pustaka Setia, 2012), h. 132.

${ }^{30}$ Bukhari Umar, Ilmu Pendidikan Islam, (Jakarta: Amzah, 2011), h. 46.

31 Ramayulis, Ilmu Pendidikan Islam., h.132.

32 Abu Ahmadi dan Nur Uhbiyati, Ilmu Pendidikan hal 112
} 
"Padahal mereka tidak disurub kecuali supaya menyembah Allah dengan memurnikan ketaatan kepada-Nya dalam (menjalankan) agama yang lurus, dan supaya mereka mendirikan shalat dan menunaikan zakat; dan yang demikian itulah agama yang lurus.”

Tujuan pendidikan Islam adalah terbentuknya anak didik menjadi hamba Allah yang taqwa dan bertanggung jawab melaksanakan pekerjaan duniawi dan ukhrowi.

\section{KESIMPULAN}

Teologi adalah sebuah paham atau pemikiran tentang peranan agama dalam mengatasi permasalahan sosial. Dalam kontek Agama Islam, kata teologi akan lebibih tepat dan bermakna apabila di kaitkan dengan kata Islam, sehingga pemahaman teologi yang dimaksud adalah teologi yang bernafaskan Islam.

Pemahaman mengenai teologi pendidikan, pada kenyatannya menghendaki adanya memasukkan konsepsi pendidikan dan atau menurunkan konsepi pendidikan pada dan dari aliran-aliran mutakallimin. Teologi pendidikan merupakan kajian konsepsi pendidikan yang di-derivasi-kan dari penalaran kritis mengenai Tuhan (teos) yang meliputi eksistensi dan "atribut" ketuhanannya

Pendidikan dalam Islam adalah suatu kegiatan yang merupakan bagian dari kegiatan dakwah. Pendidikan dalam Islam adalah pendidikan yang di dasarkan pada ajaran islam, Islam sebagai sebuah ajaran agama yang diajarkan dan di bawa oleh Muhammad SAW, yang berisikan seperangkat ajaran tentang kehidupan manusia, ajaran yang dirumuskan berdasarkan sumber pada al-quran dan hadits serta berdasarkan pemaparan rasio akal.

Dasar pendidikan Islam adalah identik ajaran Islam itu sendiri. Keduanya berasal dari sumber yang sama yaitu Al-Qur'an dan Hadits. Dasar pendidikan Islam dapat dibagi kepada tiga kategori yaitu: dasar pokok, dasar tambahan dan dasar operasional. Tujuan pendidikan Islam yang terakhir ialah terbentuknya kepribadian muslim. Yang maksudnya kepribadian muslim ialah kepribadian yang seluruh aspekaspeknya yakni baik tingkah laku luarnya kegiatan-kegiatan jiwanya, maupun filsafat hidup dan kepercayaannya menunjukkan pengabdian kepada Tuhan, penyerahan diri kepada-Nya 


\section{DAFTAR PUSTAKA}

Aat Syafaat, Sohari Sahrani, Peranan Pendidikan Agama Islam Dalam Mencegah Kenakalan Remaja 2017.

Abu Ahmadi dan Nur Uhbiyati, Ilmu Pendidikan, Jakarta: PT Rineka 2010

Beni Ahmad Saebani dan Abdul Hamid, Ilmu Akhlak, Bandung: Cv Pustaka Setia, 2012

Bukhari Umar, Ilmu Pendidikan Islam, Jakarta: Amzah, 2011

Hasan Langgulun, Pendidikan Islam Dalam Abad 21,PT Pustaka Al-Husna Baru, Jakarta 2003

Hasan Langgulung, Beberapa Pemikiran tentang Pendidikan Islam, Bandung: alMa`arif, 2001

Hasan Langgulung. Asas-Asas Pendidikan Islam. Jakarta. Al-Husna. 1987.

Irfan, Muhammad \& Mastuki HS. Teologi Pendidikan; Tauhid Sebagai Paradigma Pendidikan Islam. Jakarta, Friska Agung Insani, Cet. III, 2008.

Malik Fatoni, teologi pendidikan; Studi analisa penguatan dalam Karakteristik pendidikan islam, Jurnal Geneologi PAI Volume 1 No 1 (Januari-Juni) 2016

Mangun Budiyanto, Ilmu Pendidikan Islam, Yogyakarta: Penerbit Ombak, 2013

Mangun Budiyanto, Ilmu Pendidikan Islam, Yogyakarta: Penerbit Ombak, 2013

Mehdi Nakosteen, History of Islamic Origins of Western Education A.D. 800-1350; with an introduction to Medieval Muslim Education, University of Colorado Press, Boulder, 1964

Ramayulis, Ilmu Pendidikan Islam, Jakarta: Kalam Mulia, 2011

Saefullah. Muhammad Qutub dan Sistem Pendidikan Non-Dikotomik. Yogyakarta. Suluh Pers. 2005.

Tafsir, Ahmad. Ilmu pendidikan dalam perspektif Islam, Bandung, Rosda Karya, 2010. Hal. 182005

Zaghlul Yusuf, Ed, Pendidikan Agama Islam, analisis rangsangan Afeksi, MKDUIKIP Jakarta, 1990 